\title{
Certainty of constitutional judge
}

Thesis in the Egyptian constitutional judgment And judgment of supreme American court

$$
\begin{aligned}
& \text { الدكتــــــــور } \\
& \text { محمد عبل الآله مفازي محمود الني } \\
& \text { الأستات المساعت بقسهر القانوة الهام } \\
& \text { كلية الشريحة والقانوة بلومنهور } \\
& \text { جامحة الإززهر }
\end{aligned}
$$


$(r \circ \varepsilon)$ 


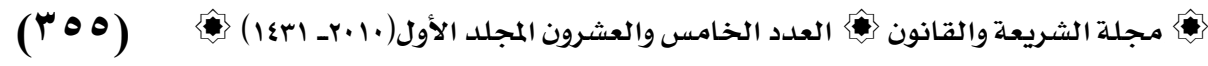

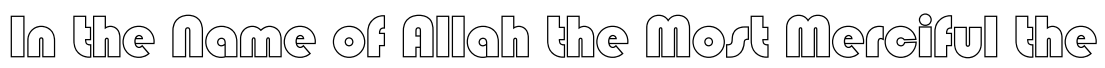

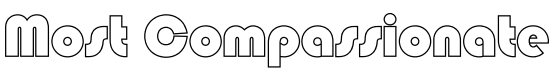




\section{Dedicated to}

\section{The Egyptian Supreme constitutional}

\section{court}

On the occasion of the 40 the anniversary of its

establishment 


\section{Preface :}

This thesis deals with the most vital topic; the task of constitutional judge, since the constitutional judgment is different in its trend and its principles from that applied to other judicial organizations, i.e., the standard and administrative judgment .

The first phase in this difference appears in the text which is used to issue judgments in some certain cases; being the text of the constitution itself , it has certain characteristics, being not a pure lawful text as indicated in the theories of right and duty in a limited way just like the civil text . Hence, the judge may have to insert an element that has no relation to legal concept of the text ; here, we can see the political role of the constitutional judge in case of practicing his role in censorship on constitutionality . On the other hand, the role of constitutional judge is characterized by being based upon the principle superiority of constitution over other legislations, consequently we may be eligible to discard certain text, issued by either legislative or executive authority. Hence, it is necessary for accuracy of investigation and check to reveal the defects in the text .

In the light of these two phases, the current thesis attempts to identify how the constitutional judge can attain certainty ; either regarding the constitutionality or non constitutionality of some certain text . 


\section{Thesis plan :}

The thesis is summarized in the following six principles:

1-The first principle:The evidence of constitutionality .

2- The second principle : Self - restriction

3- Third principle : Constitutional judgment function is technical and has a lawful nature

4- Fourth principle:View of apparent contradiction and nominal spot

5- - Fifth principle: View of second article of the constitution

6- - Sixth principle: View of constitutional judgment to the constitutional document.

- With comparison with the principles of the American Supreme Court in the case of Marburg V. Madison, issued in 1803 . 


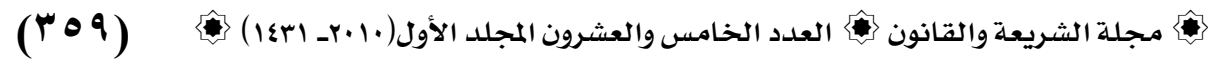

- The approach of censorship on constitutionality of laws in Egypt.

- What is meant by the approach of censorship ?

- What are the principles of censorship ?

* This approach means the settled principles of our constitutional judgment in its censorship on constitution which are represented in the following main items : 
- The first principle : The evidence of constitutionality $^{(1)}$ (its concept) : The proof is that the constitutionality is the origin of legislation, thus the proof for legislation is to be constitutional, who claims the opposite should present the proof of non constitutional, in order to be sure that legislation is constitutional .

( ${ }^{1}$ ) Collection of sentences issued by the supreme constitutional court , third partition , P. 5 . See :

Collection of sentences issued by the supreme court, $1^{\text {st }}$ partition,$P .100$

See as well :in convey to the sentence of American Supereme court in

Marbury case V. Madison ; 1 Cranch 137; 2 L. ed. 60 ( 1803), the

source is Robert F. Cushman, Cases in constitutional law ,Prentice Hall, inc.., Englewood clifts, New Jersey fifth edition . 1979 , P. 4 . The court says :

" The Constitution vests the whole judicial power of United States in one Supreme Court, and such inferior courts as Congress shall, from time to time, ordain and establish...

In the distribution of this power it is declared that "the Supreme Court shall have original jurisdiction in all cases affecting ambassadors, other public ministers and consuls, and those in which a state shall be a party. In all other cases, the Supreme Court shall have appellate jurisdiction."...

If it had been intended to leave it in the discretion of the legislature to apportion the judicial power between the supreme and inferior courts according to the will of that body, it would certainly have been useless to have proceeded further than to have defined the judicial power, and the tribunals in which it should be vested. The subsequent part of the section is more surplus age, is entirely without meaning ... the distribution of jurisdiction, made in the constitution, is from without substance ..

It cannot be presumed that any clause in the Constitution is intended to be without effect; and, therefore, such a construction is inadmissible, unless the words require it...

To enable this court, then, to issue a mandamus, it must be shown to be an exercise of appellate jurisdiction, or to be necessary to enable them to exercise appellate jurisdiction..." 
- The evidences of such principle : the supreme constitutional court and formerly the supreme court postulated the effects of such principle in :

A) The main basis is that each possible evidence should be for the interest of constitutionality of the debated legislation as long as there is no cassation on such evidence with obvious proof which violates the constitutionality of the debated text .

B) The constitutional judge shouldn't, on checking the constitutionality of laws, ignore such evidence except in case of existing an obvious contradiction between the law and constitution, the case which makes it impossible to coordinate between law and constitution , in other words, the court can't confirm the non - constitutionality except in case there is no doubt for such law to oppose constitution .

C) In case the court can interpret certain law through different views, and one of these views accords with constitution, here the court should follow such view in interpreting the law as long as its phrases express the law itself without seeking the intention of the legislator and his implicit perception .

D) stating non constitutionality for certain text within a legislation and voiding the effects of such text doesn't mean voiding the rest of the texts of that legislation as long as these texts are not completely related with the voided text. 
- The second principle : Self - restriction ${ }^{(1)}$

Self - restriction is considered one of the main principles

for constitutional judgment .

It's concept : Our constitutional judgment has restricted

itself in case of practicing judicial censorship, on the

$\left.{ }^{1}\right)$ Collection of sentences issued by the supreme constitutional court, third partition , P. 5.

Collection of sentences issued by the supreme court, $1^{\text {st }}$ partition , issued in $1^{\text {st }}$ April 1972., P. 81-82.

- See as well :in convey to the sentence of American Supereme court in Marbury case V. Madison ; 1 Cranch 137; 2 L. ed. 60 ( 1803), the source is Robert F. Cushman, Cases in constitutional law ,Prentice Hall, inc.., Englewood clifts, New Jersey fifth edition . 1979, P. 5 . The court says :

" It is the essential criterion of appellate jurisdiction, that it revises and corrects the proceedings in a cause already instituted, and does not create that cause. Although, therefore, a mandamus may be directed to courts, yet to issue such a writ to an officer for the delivery of a paper, is in effect the same as to sustain an original action for that paper, and, therefore, seems not to belong to appellate, but to original jurisdiction. Neither is it necessary in such a case as this, to enable the court to exercise its appellate jurisdiction.

The authority, therefore, given to the Supreme Court, by the Act establishing the judicial courts of the United States, to issue writs of mandamus to public officers, appears not to be warranted by the constitution; and it becomes necessary to inquire whether a jurisdiction so conferred can be exercised.

The question, whether an Act, repugnant to the Constitution can become the law of the land, is a question deeply interesting to the United States; but, happily, not of an intricacy proportioned to its interest. It seems only necessary to recognize certain principles, supposed to have been long and well established, to decide it. That the people have an original right to establish, for their future government, such principles as, in their opinion, shall most conduce to their own happiness, is the basis on which the whole American fabric has been erected. The exercise of this original right is a very great exertion; nor can it not ought it to be frequently repeated. The principles, therefore, so established, are deemed fundamental. And as the authority from which they proceed is supreme, and can seldom act, they are designed to be permanent." 
basis that such censorship has some limits that shouldn't be exceeded, and not getting through areas where both legislative and judicial authorities are practicing their estimated powers, also not to interfere in constitutional jobs of each .

But the issue in this censorship mainly depends on the restrictions which the constitution has imposed, taking into consideration that such restrictions and rights are the main issue and aim of judicial censorship practiced by the concerned court according to its aims.

\section{Consequences of such principle : This}

\section{principle has the following results :}

(A) As long as the fields of legislation practiced by the legislative authority extend to and cover all topics , as well as the convenience of legislation, being one of the main characteristics of the normal legislator powers, as long as he is not restricted by certain limits that he must follow, otherwise it will be considered unconstitutional, hence, the legislator 
has the right to lay out the lawful rules that he thinks it will accomplish public interest.

(B) It's a constitutional well known principle that the government has the power to control resolutions of organizations and establishments and all relative administrations. Moreover, government has the right to annul or amend its resolutions which are inconvenient according to law from its point of view : this is the administrative censorship.

Meanwhile, peoples' assembly has the right to control works of the executive authority as a political censorship this basically relies upon the principle of ministers' responsibility toward this council. In case such censorship reached a resolution necessities to annul resolutions issued by firms' board which are contrary to the law, hence every side has the right to abolish such resolutions, thus, the executive authority can also abolish it, and so, peoples assembly can as well abolish it 


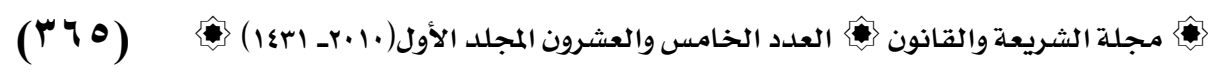

by means of law, being the sole legislative source in the state .

(C) There is what is called "organic unity" in the constitution, such unity accomplishes the integrity of the structure of constitution, at the same time eliminates any ambiguity or contradiction. 


\section{- Third principle : Constitutional judgment function is technical and has a lawful nature $\left({ }^{1}\right)$}

( ${ }^{1}$ ) Collection of sentences issued by the supreme constitutional court, third partition, P. 4.

See as well :in convey to the sentence of American Supereme court in

Marbury case V. Madison ; 1 Cranch 137; 2 L. ed. 60 ( 1803), the

source is Robert F. Cushman, Cases in constitutional law ,Prentice -

Hall, inc.., Englewood clifts, New Jersey fifth edition . 1979, P. 5 . The court says :

" This original and supreme will organizes the government, and assigns to different departments their respective powers. It may either stop here, or establish certain limits not to be transcended by those departments.

The government of the United States is of the latter description. The powers of the legislature are defined and limited; and that those limits may not be mistaken, or forgotten. The Constitution is written. To what purpose are powers limited. And to what purpose is that limitation committed to writing, if these limits may, at any time. Be passed by those intended to be restrained? The distinction between a government with limited and unlimited powers is abolished. If those limits do not confine the persons on whom they are imposed, and if acts prohibited and acts allowed are of equal obligation. It is a proposition too plain to be contested, that the Constitution controls any legislative Act repugnant to it; or, that the legislature may alter the Constitution by and ordinary Act.

Between these alternatives is no middle ground. The Constitution is either a superior paramount law, unchangeable by ordinary means, or it is on a level with ordinary legislative Acts, and, like other Acts, is alterable when the legislature shall place to alter it.

If the former part of the alternative be true, then a legislative Act contrary to the Constitution is not law; if the latter part be true, then written conceptions are absurd attempts, on the part of the people. To limit a power in its own nature illimitable.

Certainly all those who have framed written constitutions contemplate them as forming the fundamental and paramount law of the nation, and, consequently, the theory of every such government must be that an Act of the legislature, repugnant to the Constitution, is void.

This theory is essentially attached to a written Constitution, and, is consequently, to be considered, by this court, as one of the fundamental principles of our society. It is not therefore to be lost sight of in the further consideration of this subject." 
This principle means that it's forbidden for the constitutional judge to judge the constitutional issues except in case of objective dispute related to such constitutional issues.

\section{Items of this principle:}

This principle necessitates the following items :

(a) The constitutional judgment doesn't interfere with the necessity of legislation .

(b) The constitutional judgment doesn't control the convenience or wisdom of legislation .

(c) The constitutional judgment considers the outline of legislation as a base for inspecting how far it is constitutional .

(d) The constitutional judgment doesn't have any relation with the political issues.

(e) The constitutional court doesn't limit itself within the form described by the legislator on the rules even in case of contradiction with such description .

(f) Once, if the legislative authority tried to practise a prohibited action under any condition and imposing a rule, it would be illegal action which should be abolished by judgment . 
-Fourth principle : View of apparent contradiction and nominal spot ${ }^{(1)}$

This principle means that the violation for the constitution is based on the visible issue for the text at the beginning of contacting with judgment , hence such suspect necessitates the court to make sure of the truth by demonstrating it on the

( ${ }^{1}$ ) Sentence of court in the plea No. 102 , in the year $12 \mathrm{~L}$, issued in 19 June 1993 , rule no. 10 , form lawyer magazine Aug, 1994 , second partition , P 87-88.

See as well :in convey to the sentence of American Supereme court in Marbury case V. Madison ; 1 Cranch 137; 2 L. ed. 60 ( 1803), the source is Robert F. Cushman, Cases in constitutional law ,Prentice Hall, inc.., Englewood clifts, New Jersey fifth edition . 1979, P. 5-6 . The court says :

" If an Act of the legislature - repugnant to the Constitution, is void, does it, notwithstanding its invalidity, bind the courts, and oblige them to give it effect? Or, in other words, thought it be not law, does it constitute a rule as operative as if it was a law? This would be to overthrow in fact what was established in theory; and would seem, at first view, an absurdity too gross to be insisted on. It shall, however, receive a more attentive consideration.

It is emphatically the province and duty of the judicial department to say what the law is. Those who apply the rule to particular cases, must of necessity expound and interpret that rule. If two laws conflict with each other, the courts must decide on the operation of each.

So if a law be in opposition to the Constitution; if both the law and the Constitution apply to a particular case, so that the law, disregarding the constitution; or conformably to the Constitution, disregarding the law, the court must determine which of these confliction rules governs the case. This is of the very essence of judicial duty.

If, then the courts are to regard the Constitution. And the Constitution is superior to any ordinary Act of the Legislature, the Constitution, and not such ordinary Act, must govern the case to which they both apply.

Those then, who controvert the principle that the Constitution is to be considered, in court, as a paramount law, are reduced to the necessity of maintaining that courts must close their eyes on the Constitution, and see only the law." 
supreme constitutional court so as to judge the issue .

\section{Items of this principle:}

This principle necessitates the following items from the constitutional judgment :

a) The constitutional legislation : which the supreme constitutional court controls abiding by it. Its aim at that the legislative texts should be in accordance with the constitution rules.

b) The existence of non- constitutionality necessitates the courts to make sure of its truth by demonstrating it on the supreme constitutional court which is the sole authority that judges the constitutional issues.

c) The nature of lawful censorship practiced by the court of cassation on the court of issue doesn't put off the claim of non- constitutionality; meanwhile inspecting the case in such condition represents the real meaning of its lawful censorship . 
- Fifth principle: View of the second article of the constitution $^{(1)}$

This principle means that the constitution has declared in its second article that the Islamic legislation is the main source of legislation, and any sentence contradicts the Islamic legislation deemed void.

Items of this principle :

( ${ }^{1}$ ) Sentence of court in the plea No. 9 , in the year $11 \mathrm{~L}$, issued in 19 June 1993 , rule no. 10 , form lawyer magazine Aug, 1994 , second partition , P 103104 ..

- See as well :in convey to the sentence of American Supereme court in Marbury case V. Madison ; 1 Cranch 137; 2 L. ed. 60 ( 1803), the source is Robert F. Cushman, Cases in constitutional law ,Prentice Hall, inc.., Englewood clifts, New Jersey fifth edition . 1979 , P. 6 . The court says :

"This doctrine would subvert the very foundation of all written constitutions. It would declare that an Act which, according to the principles and theory of our government, is entirely void, is ye, in practice, completely obligatory. It would declare that if the legislature shall do what is expressly forbidden, such Act, notwithstanding the express prohibition, is in reality effectual. It would be giving to the legislature a practical and real omnipotence, with the same breath which professes to restrict their powers within narrow limits. It is prescribing limits, and declaring that those limits may be passed at pleasure.

That it thus reduces to nothing what we have deemed the greatest improvement on political institutions, written constitution, would of itself be sufficient, in America, where written constitutions have been viewed with so much reverence. For rejecting the construction. But the peculiar expression of the Constitution of the United States finish additional arguments my self or its rejection.

The judicial power of the United States is extended to all cases arising under the Constitution.

Could it be the intention of those who gave this power, to say that in using it the Constitution should not be looked into? That a case arising under the Constitution should be decided without examining the instrument under which it arises?". 


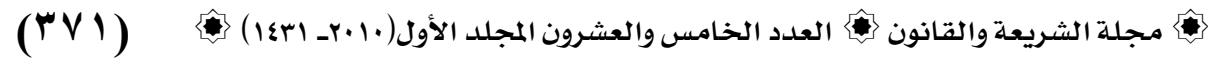

This principle was formulated by constitutional judgment in the following points:

a) The meaning of not contesting the second article is that any legislative text shouldn't oppose the fixed legislative rulings, such rulings can't be changed anyway and are inspired from the principles of Islamic legislation. Thus, it's impossible to change it's concept even if there is a change in time and place.

b) The second article of constitution considers the Islamic rulings prior to the local rulings in its basics and principles .

c) The previous ruling is different from the (doubted ) rulings either in its evidence or in its significance , or both together. This is only because the field of doubt in it is limited. It, as well, changes by the change of time and place so as to be elastic according to the change of individuals and their legal interests, at the same time, such a change should be in accordance with the Islamic legislation provided that it shouldn't violate the main Islamic regulations .

d) Islamic legislation has elasticity in so far as it can maintain and cope with development forever so as to be able to face individuals' changeable interests and needs . These are the roots of the Islamic legislation ; elastic and not stiff, since it sometimes deduce a final decision - which was not included in the Islamic legislation- after exerting some effort to reach that decision . 
e) We are sure that Allah the Almighty put down the Islamic legislation for the interests of all individuals, and never ignored any interest of them. It was postulated that the real interests are mentioned in the text, and opposing these text regulations is deemed to be contesting to Almighty regulations, at the same time, any interest contests the Quranic text is not considered a real interest, hence it shouldn't be considered in judgment . 
- Sixth principle: View of constitutional judgment to the constitutional document ${ }^{(1)}$.

( 1 ) Sentence of court in the plea No. 17 , in the year $14 \mathrm{~L}$, issued in $14 \mathrm{Jan}$ 1995, form lawyer magazine April, $1995,1^{\text {st }}$. partition , P 25-26 .

See as well :in convey to the sentence of American Supereme court in Marbury case V. Madison ; 1 Cranch 137; 2 L. ed. $60(1803)$, the source is Robert F. Cushman , Cases in constitutional law ,Prentice - Hall, inc.., Englewood clifts, New Jersey fifth edition . 1979, P. 6 . The court says :

"This is too extravagant to be maintained. In some cases, then, the Constitution must be looked into by the judges. And if they can open it at all, what part of it are they forbidden to read or to obey?

There are many other parts of the Constitution which serve to illustrate this subject. It is declared that "no tax or duty shall be laid on articles exported from any State." Suppose a duty on the export of cotton, of tobacco, or of flour; and a suit instituted to recover it. Ought judgment to be rendered in such a case? Ought the judges to close their eyes on the Constitution, and only see the law? The constitution declares "that no bill of attainder of ex post facto law shall be passed." If, however, such a bill should be passed, and a person should be prosecuted under it, must the court condemn to death those victims whom the Constitution endeavors to preserve?

"No person," says the Constitution, "shall be convicted of treason unless on the testimony of two witnesses to the same overt act, or on confession in pen court".

Here the language of the Constitution is addressed especially to the courts. It prescribes, directly for them, a rule of evidence not to be Departed from. If the legislature should change that rule, and declare on witness, or a confession out of court, sufficient for conviction, must be constitutional principle yield to the legislative Act? From these, and many other selections which might be made, it is apparent, that the framers of the Constitution contemplated that instrument as a rule for the government of courts, as well as of the legislature.

Why otherwise does it direct the judges to take an oath to support it? This oath certainly applies in an especial manner to their conduct in their official character, How immoral to impose it on them, if they were to be used as the instruments, and the knowing instruments, for violating what they swear to support! " at the end of the sentence the court decided : "The oath of office, too, imposed by the legislature, is completely demonstrative of the legislative opinion on this subject. It is in these words: "I do solemnly swear that I will administer justice without respect to persons, and do equal right to the poor and to the rich; and that I will faithfully and impartially discharge all the duties incumbent on me as according to the best of my abilities and understanding agreeably to the Constitution and laws of the United States." Why does a judge swear to discharge his duties agreeably to the Constitution of the United States, if that Constitution forms no rule for his government - if it is closed upon him, and= 
This principle means that it became necessary for the supreme constitutional court to react to the constitutional document .

=cannot be inspected by him? If such be the real state of things, this is worse than solemn mockery, to prescribe, or to take this oath, becomes equally a crime. It is also not entirely unworthy of observation, that in declaring what shall be the supreme law of the land, the Constitution itself is first mentioned; and not the laws of the United states generally, but those only which shall be made in pursuance of the Constitution, have that rank.Thus, the particular phraseology of the Constitution of the United States confirms and strengthens the principle, supposed to be essential to all written constitutions, that a law repugnant to the Constitution is void; and that courts, as well as other departments, are bound by that instrument.

The rule must be discharged." Ibid , conveyed from P.6 


\section{Items of this principle:}

This principle requested the constitutional court of the following :

a) Censorship on constitutional legacy assumes that there is a firm written constitution which found its rulings on a lawful bases, hence, the constitution is the main guarantee to rescue popular will towards its higher example, and in particular in the field of settling the system for rule provided that this system not to be based on sovereign ruling and controlling the government, but to apply democracy in the process of distributing powers among the various branches in a way that guarantees the balance and mutual censorship .

b) The basic aim of constitution - according to texts expressing the ambitions of individuals, fixing the responsibilities of those who are in charge with constitution, nullifying regulations and restrictions which prevent the achieving the safer borders of rights and freedoms and, at the same time, deterring the muddle or deviation by means of sanction . Above all, constitution seeks for the interest of the group including all the freedoms .

c) The constitutional legacy is the sole power that guarantees dependence of authority on public will , and directs any deviation to the right path by means of the basics for the group and paves the way for progress . 


\section{Legislative update via act 184 in 2008 :}

item 41 showed the general rules in how to issue sentences from the supreme constitutional court via the session fixed by head of the court within a week from the date of the jury report, at the same time, clerk office should be officially informed of the date of session, which should be at least fifteen days ; except if court chairman has changed the date in emergency cases .

The legislator, as well validated set the court up inside the debate room in accordance with article 44 repeated, added to act 184 in 2008 which was published in official newspaper, volume 25 (A) in $22 / 6 / 2008$, page 8 , year 51 , hereinafter the text of the item :

\section{Text of the item no. 44 repeated :}

The action of setting the court inside the debate room is an exception action of article 41 of that act . Such cases which are remitted to the court from court chairman, which the jury thinks that such cases are beyond the specialties of the court, or even are not accepted in form, or it was prejudged ; otherwise in one of the former cases, the court has to issue a decision to be officially mentioned in the session enclosed with a hint for the reason of the decision, otherwise the court has to remit it to jury so as to reconsider it once again and prepare a report on the issue. 


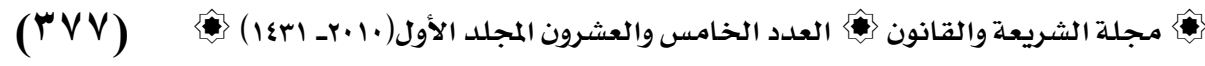

\section{Comparison :}

- We noticed that the American supreme court usually adopts the American constitutional law issued in 1787 and its amendments .

- There are few texts for that constitution ; thus the supreme court has many choices in interpreting the constitutional texts according to evolution of the constitutional law and policy systems •

- Whereas in Egypt, we see the supreme constitutional court doesn't follow the same rule as there are plenty of constitutional texts that cover almost all details . 


\section{Conclusion :}

The current thesis found that the supreme constitutional court has put down some main principles as follow :

1- The first principle : The evidence of constitutionality .

2- The second principle : Self restriction

3- Third principle : Constitutional judgment function is technical has a lawful nature

4- Fourth principle : View of apparent contradiction and nominal spot

5- - Fifth principle: View of second article of the constitution

6- - Sixth principle: View of constitutional judgment to the constitutional document.

Meanwhile, Mr. Chief justice Marshall has declared some other main principles which are adopted by jurisdiction of American supreme court in many later cases . 
References

(1) Collection of sentences issued by the supreme constitutional court , third partition .

- Collection of sentences issued by the supreme court, 1st partition .

(2) Collection of sentences issued by the supreme constitutional court, third partition, Collection of sentences issued by the supreme court, 1st partition , issued in 1st April 1972.

(3) Collection of sentences issued by the supreme constitutional court, third partition .

(4) Robert F. Cushman, Cases in constitutional law ,Prentice - Hall, inc.., Englewood clifts , New Jersey fifth edition . 1979 .

(5) Sentence of court in the plea No. 102 , in the year $12 \mathrm{~L}$, issued in 19 June 1993 , rule no. 10 , form lawyer magazine Aug, 1994 , second partition . 
( 6 ) Sentence of court in the plea No. 9, in the year $11 \mathrm{~L}$, issued in 19 June 1993 , rule no. 10 , form lawyer magazine Aug, 1994 , second partition .

( 7 )Sentence of court in the plea No. 17 , in the year $14 \mathrm{~L}$, issued in 14 Jan 1995 , form lawyer magazine April, 1995 , 1st. partition . 
Table of Contents

\begin{tabular}{|l|l|}
\hline \multicolumn{1}{|c|}{ Topic } & Page \\
\hline Preface. & \\
\hline Thesis plan . & \\
\hline The first principle • & \\
\hline The second principle . & \\
\hline The third principle • & \\
\hline The forth principle • & \\
\hline The fifth principle . & \\
\hline The sixth principle. & \\
\hline Conclusion . & \\
\hline References • & \\
\hline table of contents . & \\
\hline
\end{tabular}




\section{Certainty of constitutional judge}

Thesis in the Egyptian constitutional judgment And judgment of supreme American court

\section{Dr. Mohamed Abd Allah Moghazy}

Assistant Prof. of public law.

Al Azhar University.

Faculty of Sharia'ah and law.

Department of public law.

Damanhour

$2010-1431$

$1^{\text {st }}$. Edition 